\title{
Eugenia Lean, Public Passions. The Trial of Shi Jianqiao and the Rise of Popular Sympathy in Republican China
}

Jérôme Bourgon

\section{CpenEdition}

Journals

Electronic version

URL: http://journals.openedition.org/chinaperspectives/4273

DOI: $10.4000 /$ chinaperspectives.4273

ISSN: 1996-4617

\section{Publisher}

Centre d'étude français sur la Chine contemporaine

\section{Printed version}

Date of publication: 1 July 2008

Number of pages: 154-155

ISSN: 2070-3449

\section{Electronic reference}

Jérôme Bourgon, «Eugenia Lean, Public Passions. The Trial of Shi Jianqiao and the Rise of Popular Sympathy in Republican China », China Perspectives [Online], 2008/3 | 2008, Online since 01 July 2008, connection on 22 September 2020. URL : http://journals.openedition.org/chinaperspectives/4273 ; DOI : https://doi.org/10.4000/chinaperspectives.4273

This text was automatically generated on 22 September 2020 .

(c) All rights reserved 


\title{
Eugenia Lean, Public Passions. The Trial of Shi Jianqiao and the Rise of Popular Sympathy in Republican China
}

\author{
Jérôme Bourgon
}

On 13 November 1935, a young woman slipped into a Buddhist temple in Tianjin and fired several shots at a peaceable 50- year-old man kneeling in front of the altar. Turning towards the witnesses who were beginning to run away, the young woman threw down her weapon and began to explain her act aloud, while distributing a mimeographed document. Her name was Shi Jianqiao, the daughter of Shi Congbin, who ten years earlier had been the officer commanding the units in Shandong on behalf of the Zhili clique led by the warlord Zhang Zuolin. In October 1925, during the second war between the Zhili and Fengtian cliques, Shi Congbin had been captured by Sun Chuanfang, one of the leaders of the Fengtian clique, who had had him summarily decapitated and his head mounted on a pike. It was this Sun Chuanfang, now retired and a convert to Buddhism, whom Shi Jianqiao had just assassinated, thus exacting vengeance for her father's death and the profanation of his remains.

2 This news story immediately received considerable coverage, both because of the personality of the victim - Sun Chuanfang embodied the worst outrages of the warlords: fierce repression of workers' strikes in Shanghai, opium trafficking, collaboration with the Japanese - and the motive for the murder: avenging one's father was a crime in the eyes of the law, but a duty according to Confucian morality. This dilemma inflamed public opinion, and articles in the press were soon supplemented by serial novels, plays, and even a film, all during the proceedings of a court case full of sudden new developments, with the Tianjin District Court, the Hebei Provincial Court, and the Supreme Court in Nanking each handing down contradictory verdicts. 
3 In the end, Shi Jianqiao was given a pardon and set free. Her act had made her a heroine of filial piety, and Nationalist propaganda made her into a symbol of the Patriotic War, representing legitimate vengeance against the Japanese aggressor. The final chapter of the book follows the heroine's destiny in Communist China, the difficulties she experienced when the Cultural Revolution made filial piety a defect of feudal society, and her rehabilitation in 1979, shortly before her death.

4 This is a dense book in which the wealth of documentation and the range of points of view get the better of rigorous analysis. The initial chapters are devoted to introducing the victim, the murderer, and her motive, and then to an overview of the press. It is here that the dominant theme of the book appears: "Media Sensation: Public Justice and the Sympathy of an Urban Audience" (the title of Chapter 2) - how a newly urbanised audience supported a character draped in the chivalrous virtues of the wuxia, those righters of wrongs in Chinese popular novels. The case gives rise to a confrontation between a feeling of sympathy for the murderess, qing; reason, li; and the law fa, with the first generally getting the better of the other two, according to the author's analysis of the court case. Shi Jianqiao was defended by two "ace lawyers" who made two primary submissions on her behalf: on the one hand, shi had immediately surrendered to the authorities, zishou, an important notion in old law, which the author believes led automatically to a pardon, when in fact it was never more than a mitigating circumstance. On the other hand, the lawyers pleaded "rightful anger" in the face of the unjust and barbarous act of which the accused's father had been the victim, in a situation - the chaos of civil war - in which she could not obtain justice by any other means.

5 Specious reasoning, replied the public prosecutor, since vengeance was exacted ten years after the deed, when the restoration of Republican institutions would have allowed a proper court case to be brought. The death of a father, the prosecutor went on, cannot justify private vengeance, and submission to the law is not in itself a reason for clemency; the circumstances must be examined from the perspective of the higher interests of respect for the law and for public order, and not according to feelings of "sympathy" of dubious foundation.

6 The judicial authorities sought in this way to spread the principles of modern law by undermining old concepts such as "One cannot live under the same sky as one's father's murderer," which were still very widespread among the public. However, they found support in a public opinion that was already modern, which is to say divided. Thus the intellectual left was consistently hostile to Shi Jianqiao's deed and to the worship accorded to her. A journalist remarked, "Our society has always sympathised with these avengers, feeling that their deeds were 'exciting' (renao), and cheering them on for no reason, shouting 'Bravo!' In fact, every time a criminal acts with determination, people in the street make themselves hoarse shouting, “Well done!”' (p. 103).

7 Sinologists will be pleased to learn here that the great lawyer and historian of Chinese law, Xu Daolin (Hsu Tao-lin), resigned from the high judicial office he held under the Nationalist Republic in order to prosecute, "as an ordinary citizen," the warlord who had had his father murdered, but without success, leading him to subsequently resort to an academic career. While $\mathrm{Xu}$ always blamed himself for this failure, he never regretted not attempting to impose justice himself. Moreover, appearances notwithstanding, the impunity enjoyed by the ruffian who had murdered Xu Daolin's father, and the pardon granted to Shi Jianqiao and other avenging murderers, did not 
depend on legal debates, but on intrigues between Chiang Kai-shek and the former warlords who had rallied to his cause. The pardoning of Shi Jianqiao makes more sense when one learns that she had the support of Feng Yuxiang, the former leader of the Zhili clique, who remained very influential under the Nationalist Republic.

8 As is common among sinologists, the author tends to overemphasise Chinese specificity. What is so specifically Chinese about the defence putting forward exceptional circumstances to excuse a crime, or the prosecutor emphasising respect for law and public order? Does relating the former to Confucianism and the latter to legalism shed light on the historical and philosophical background of the decision, or does it merely surrender to a sinological cliché that actually conceals our ignorance? The book lacks the historical perspective and document based comparative approach that would allow a comprehensive exploration of the "sympathy" and "emotions" of the public. While European historians have at their disposal a vast store of songs, illustrated lampoons, and rhyming verses that allow them to study the feelings aroused in the public by trials and executions since at least the sixteenth century, why do historians of China have virtually no such materials, to the point where the case of Shi Jianqiao appears, in 1935, to signal a new awareness of legal cases? This book does not answer that question, but it does have the merit of asking it with great acuteness, and with a wealth of detail. 